LORRAINE GAUTHIER teaches in and is co-ordinator of the bilingual Women's Studies programme at Glendon College, York University. This article forms a part of a project in which the author intends to present to anglo-feminists a detailed analysis of Luce Irigaray's views on language, sexuality and motherhood.

\title{
Desire for Origin / Original Desire:
}

\author{
Luce Irigaray on Maternity, Sexuality and Language
}

\section{LORRAINE GAUTHIER}

FRENCH "FEMINIST" THEORISTS of "différence" focus on the relationship of the sexed body to symbolic discourse. Luce Irigaray's contribution addresses the projection of men's psycho-sexual relation to the "mother's body" and the specificity of the woman's "sexual body". Both of these bodies occupy an important position in the ubiquitous metaphors which form the basis of our language systems. Irigaray argues that this relationship between the sexed body and language is essential to the construction of symbolic discourse per se, and is, as well, the very "source" of our oppression, the main "site" of our subjugation. She raises two fundamental questions: what is the relationship between the physiological and the symbolic, between the body and language; what place do women as mothers occupy within this relationship, and by extension, what effect does this place have on women as women within our society?

For Luce Irigaray, philosophy is the basis of all discourse, including psychoanalytic discourse, whose privileged object is the analysis of the "subject" and of human sexuality. A major portion of her work analyses traditional philosophy, from Plato to Derrida, by using psychoanalytic concepts of repression and repetition and deconstructive notions of the metaphoricity of all discourse. Irigaray exposes the desire for origin, for symmetry, for unity, for solidity and for the visible which underlies "phallomorphic" discourse. These exclude the very possibility of any other discourse, any other relationship to "others" and to the "world" unless that "other" is inscribed as opposite, negative, or mirror image. The desire for origin, for the mother, for the intra-uterine existence which has been lost refuses to grant this "origin" a desire of its own, or to see those whose bodies are identifiable with that "origin" as being other than the mothers, in an endless repetition, retrieval, repression. Obliterated is the symbolic representation of women as women, as well as the relationship 
between mothers and daughters, the black continent within the black continent, as Irigaray so aptly describes it.

The question of the repression of our origin, of our birth, of our physical relationship with our mother's sexed body and of the impact of this repression on sexual difference is perhaps, as she suggests, the major issue which our era is addressing. Attempts at getting to the origin of the question, to the question of origin, have too often floundered in an unrecognized metaphoricity of language in which men's projections still predominate. The two most recent "subversive" thinkers of our times, who have attempted to deconstruct and decentre the subject, are themselves caught within their own web of repressed desire and their own metaphoricity of identity, form, solidity and visibility. Both Derrida's literal trace and Lacan's mirror image presume the solidity of surface, a solid support, and privilege the scopic which distances the letter and the image from the eye which sees but never touches. Neither the trace nor the image can be produced without simultaneously reproducing, hence neither has origin, only effect. Derrida and Lacan repudiate the very notion of origin within their theoretical "scope". Derrida rejects, and as Irigaray would have it, represses the "logos" as original voiced presence. For Lacan, origin is the very lack of origin, the "manque" as primary division, as gap, as "l'hommelet" (placenta), lost and discarded. But for Irigaray either affirming or denying transcendental origin comes to the same repression, that of the physical relationship to the mother's body.

The repression of the mother's sexed body is not, as Lacan, Kristeva and others would have it, a necessity for the entrance into the symbolic, but rather, in Irigarean terms, the impediment to the very possibility of any real symbolic and sexual exchange. What is repressed along with the mother's sexed body is sexual difference and specifity. This is not, she asserts, a mere reduction to anatomical difference. Rather than oppose the biological determinism of Freud's "anatomy is destiny" by privileging the social construction of sexed categories, Irigaray is attempting to uncover the relationship which male dominated discourses have continuously denied: the intricate relationship between woman's body and language and the irreducible "différence" of the female body and experience which cannot be expressed as a mere difference "from" any one particular privileged signifier, i.e. the phallus.

The issue for Irigaray is not only to retrieve corporeality. It is especially a question of recognizing the difference in differently sexed bodies and the role of that difference and its repression in the elaboration of the metaphors which underlie our sexual symbolic representations. She wishes to unmask the myth of "language" as neutral, a neutrality which in effect is masculine, and, unrecognized as such, is presented as universal in opposition to the "specificity" of female language. This supposedly neutral language, linked to male physiology, devalues or excludes the multiplicity, fluidity and flux of female experience which finds itself unrepresented and un- 
representable. For Irigaray, both sexes speak a "specific" language, each from the position of "other". It is only when this is recognized that each will be able to speak to the other. For this to happen women must be allowed to develop our language, our symbols with which to express our "selves", our experience, and in such expression discover ourselves as true other, as women, not as "other" to the one.

The same philosophical and linguistic méconnaissance lies at the base of prevailing psychoanalytic theory. It proves to be yet one more speculation, specularisation of male desire in which women can never become women but must always be either men, "la petite fille est alors un petit homme", or mothers, "le bonheur conjugal restant mal assuré tant que la femme n'a pas reussi à faire de son époux son enfant"1 This latter is our only feminine role which we must fulfill by being "like a mother" (comme la mère), like our mother, like his mother, with whom we nevertheless do not identify. It is the "place" of motherhood to which we aspire, a place now filled by one whom we have learnt to devalue and whom we must oust from place in order to occupy it ourselves. Hate and rivalry, not love and identification are the results, with devastating effects on both women and mothers. Women never achieve the status of "sexed" being, are always reduced to a sexless reproductive womb. As idealized mothers our genitalia are veiled with denial or when represented, as in pornography, are so as effect of this denial which reduces them to insatiable holes to be violently subjugated. This violation masks the threat of uterine reabsorption and hence of annihilation experienced by men's unconscious and unanalysed desire for origin.

Irigaray attempts to reanalyse the construction of the sexed subject within the patriarchal triadic family. Her starting point is Freud's theory of the oedipal complex and Lacan's notions of the mirror phase and the "nom/non du père" as the separation of the mother/child dyad which induces the child's individuation and entrance into the symbolic. What is excluded from these concepts is the mother daughter relationship, since within the paradigm of psychoanalytic theory itself, a woman's relationship to her origin is obliterated from the very beginning, in the necessity for her to turn against the mother and form a relationship with the father. This rejection of the mother is constructed and maintained by masculine

1. "the little girl is then a little man" and "a marriage is not made secure until the wife has succeeded in making her husband her child as well." quoted from Freud's "Feminity" in Luce Irigaray's Speculum de l'autre femme (Paris: Minuit, 1974), p. 26, and Ce sexe qui n'en est pas un (Paris: Minuit, 1977), p. 42. 
discourse which has symbolically represented men's relationship to origin as the only relationship possible. Opposing Kristeva's notion that both sexes have a relationship to the semiotic pre-oedipal language, Irigaray points out that women are denied access because the dominant discourse offers us no language, no means of symbolisaton with which to trace our way back. Our inability to articulate our repressed semiotic elements produces in us hysterical somatic symptoms, or leads us to excessive identification with phallic discourse and power, as an extension of our identification with the father.

The repression of origin, of desire for origin is also a repression of our original desire and hence of all desire. Women's sexual specificity has no symbolic representation through which women as sexual beings can identify with other women in a validating non-maternal role. Women's fluidity, flux and multiplicity, which lie at the base of our bodily experience of the "other" and of the "world", are inexpressible since the patriarchal family and phallic discourse offer but one symbol with which women can have but a negative relationship. What is needed according to Irigaray is a movement from infant individuation from the mother, to retrieval of the mother, to beyond the mother towards the woman, a movement with symbolic representations specifically reflecting women's experience. We must find our way back to our mothers via the creation of female goddesses (not fertility figures) whose existence would give us a symbolic language through which we can return to our origin, in order to go beyond. Otherwise women's perpetual exile from our primary maternal territory, our fundamental privation which Kristeva suggests may in fact be our castration, will forever block our full entrance into the symbolic.

The beyond, however, seems difficult to envisage and to theorize without falling back into the negation/repression which Irigaray exposes as the basis of male discourse. She insists that we cannot relate to, nor love, the other without first relating to and loving the same (la même). Yet she speaks of the need for women to mourn their mothers, in order to recognize and relate to the women who have, so far, been veiled by the term and the role of "mother". As opposed to melancholia, where part of the ego has identified with the object from whom libidinal attachment must be withdrawn, mourning is the slow process by which the libido successfully detaches itself from one object onto another. As such, mourning could complete the infantile movement away from the mother which necessitated a negation of her as same, a construction of her, as "Other". It is this need for negation of identity, of sameness, which poses the problem. Our mothers, as original love-object, can never be totally abandoned. As in melancholia, it is not so much a question of "whom" we have lost, but of "what" we have lost in the loss of the loved object (the mother) ${ }^{2}$ With the

2. Sigmund Freud, "Mourning and Melancholia", in General Psychological Theory (New York: Collier, 1974), p. 166. 
added burden of a problematic identification with our mothers, how do we navigate between mourning and negation without the former flowing inextricably into the latter? Can we as women be any more successful at mourning that loss than men have been, granted that our loss is different?

What is repressed in her demand for a validating symbolisation of women which plays down if not bypasses our roles as mothers? Is she not running the risk of once more repressing the mother as original desire? It is our desire for origin/original desire which has been repressed by male discourse and which needs symbolic representation. Can this desire of ours for our origin be expressed through a symbolic denial of women as mother? Does our origin as women lie elsewhere than in our mothers? Are we not deluding ourselves if we attempt to represent ourselves symbolically as women without re-presenting our origin, if we attempt to go beyond the mother to the woman who hides "behind", and on to our selves? Would this not end up granting a monopoly to men's representations of the mother, and indeed, would our denial not reinforce their negation? In fact, can we sidestep our mothers, the mother in us, on our way to the women in them, to the woman in us? This woman beyond the mother may be unreachable, if not inexistent, for as long as we are "of woman born".

Perhaps we must break more radically with the devaluation of our mothers, of us as daughters to a mother, upon which the theory of the phallus has insisted. Irigaray implies as much in her emphasis on the role of desire for origin/original desire both in men's symbolic projections and for the liberation of the repressed in women. This is an emphasis which is belied in her explicit insistence on the symbolic validation of women as women and on the need to go beyond the mother. Yet the metaphorical slippages in her two essays "L'une ne bouge pas sans l'autre" and "Quand nos lèvres se parlent" bind maternity and women's sexuality to such an extent that each essay, though presumably concentrating on one or the other, can be read as referring to both motherhood and sexuality. Both the inability for autonomous movement and the communication between our lips refer to mother/daughter relationships and to the female genitalia whose labia (lips) are so central to Irigaray's discussion of female sexuality. These essays are a clear indication of how difficult it is to separate our relationship to our bodies and to other women from our maternal ties, repressed or not.

But this is no mere oversight on her part. For Irigaray, the collapsing of woman into mother is itself a phallic reduction, necessitated by the male desire for origin/original desire. It all but obliterates woman as an autonomous sexual being whose sexuality, when broached, is discussed in phallic terms, not in terms of our own experience and potentialities which she wishes to unearth from centuries of male projections and denials. She decries the role assigned to women as the social unconscious of male desire. Would the unconscious be the same in a non-phallic society she asks? She insists that it has always been and continues to be a question of the 
outright suppression of women's bodies, of the mother's sexed body beneath the image of the castrated mother, occulted in her sexual neutrality. For her, if there has been any social necessity, it has been the need for this repression in order to constitute and maintain phallomorphic discourse. Hence her insistence on the creation of symbols more pertinent to female experience and specifically to women as women.

Can we avoid this phallic reduction of women as mothers by recognizing mothers as women, as sexed beings, without separating the two? There, of course, lies the crux of the problem. As she has so aptly demonstrated, men have been unable to do so and have separated motherhood and sexed womanhood, denying sexuality to the first and maternity to the second. Must we maintain that separation while merely affirming in a specific and positive way the sexuality of women? Is it merely a question of oppression, or are we not facing a perhaps insoluble and inevitable repression? The distinction between the two is sometimes lost in our attempt to recapture what men have so brutally negated.

Julia Kristeva's analysis of the semiotic gives us some sense of the strength of the psychoanalytic and physical bonds with the mother, though her prescription that women's role in society be a negative one, in which women constantly expose the gaps in masculinist symbolic discourse, leaves little for women to do as positive agents of our liberation. However, her analysis of the necessity to break the intimate bodily semiotic links with the mother, in order to enter symbolic discourse, must be carefully examined in order to address the complex problem of the seemingly insurmountable love/hate, desire/rejection of the mother as mother. Irigaray has criticized this break as the site of women's oppresion and repression within a phallic order. Can we go beyond this and theorize a non-phallic break in our intimate relationship with our mothers or must we reformulate the entire question of this break, of this creation of other, of Other?

It is not merely a question of going beyond the mother but of retrieving her and keeping her with us in a manner that allows both her and us to be same and other. As Irigaray claims, women are never just one, they are always at least two: mother (potential or real) and women (potential or real). Does the difficulty not lie in our inability to separate ourselves in two? Can the same not be said of our oppression? If exile from our primary maternal territory is our castration, then this denial of our desire for origin/original desire is also a denial of desire itself and of the language which mediates between the two. Symbolic representations of our mothers as sexed beings, as women of desire may be the means of assuring identity and otherness for both of us in order to liberate our desire, our selves. For as Irigaray clearly points out in "L'une ne bouge pas sans l'autre", the mother is as enmeshed in her desire for, identification with and separation from the child as is the child with her. The symbolisation of women as women may not untangle this web of desire and identification and by producing yet another mother/woman split may repeat and reinforce the virginmother/whore split of phallic discourse. 